\title{
Occurrence of White Top of Pea Caused by a New Strain of Pseudomonas syringae pv. pisi
}

A. Suzuki, Laboratory of Plant Pathology, Faculty of Agriculture, Shizuoka University, Shizuoka 422-8529, Japan; M. Togawa, Shizuoka Prefecture Agricultural Experiment Station, Toyoda, Iwata Shizuoka 438-0803, Japan; K. Ohta, Shizuoka Citrus Experiment Station, Mikkabi, Inasa Shizuoka 431-1416, Japan; and Y. Takikawa, Laboratory of Plant Pathology, Faculty of Agriculture, Shizuoka University, Japan

\begin{abstract}
Suzuki, A., Togawa, M., Ohta, K., and Takikawa, Y. 2003. Occurrence of white top of pea caused by a new strain of Pseudomonas syringae pv. pisi. Plant Dis. 87:1404-1410.

A new bacterial disease has been observed on pea in Shizuoka prefecture, Japan, since 1981. The disease occurs in early autumn when pea plants grow vigorously. The disease is characterized by chlorosis and whitening of apical shoots, including leaflets, stipules, and young pods. Usually, these white top (WT) symptoms are associated with extensive water-soaked lesions on stems and on leaflets at the basal part of the diseased plants. Thirty-four bacterial isolates from WT plants were characterized and identified together with 16 strains of Pseudomonas syringae pv. pisi from common bacterial blight of pea. The bacteria were gram-negative rods, having one to six polar flagella. The results of LOPAT tests were +---+ , showing that they belong to $P$. syringe. In stab inoculation on stems, the WT isolates produced WT symptoms with watersoaked spots 14 days after inoculation. The 16 P. syringae pv. pisi strains never induced WT symptoms and, on the contrary, caused the typical bacterial blight. WT isolates were not pathogenic on any other plants tested. Phenotypic properties differentiated WT isolates and P. syringae pv. pisi strains into two groups; one consists of WT isolates and P. syringae pv. pisi group A, the other is $P$. syringae pv. pisi group B. Two distinct fingerprint profiles were identified by repetitive sequence based-polymerase chain reaction. WT isolates and $P$. syringae pv. pisi group A belonged to the same fingerprint type in rep-PCR, whereas a distinct fingerprint was shown by strains of the P. syringae pv. pisi group B. We concluded that the WT isolates should be included in $P$. syringae pv. pisi as a distinct strain in symptom expression.
\end{abstract}

In 1981, a disease of unknown cause characterized by white top (WT) appearance was first observed on pea in the Izu district of Shizuoka Prefecture, Japan, one of the major pea-production areas. Symptoms developed as conspicuous apical shoot chlorosis and whitening, which did not resemble any diseases caused by known pathogens of pea. The symptoms of the WT disease usually are associated with water-soaked lesions typical of bacterial blight. The WT symptoms have some similarity with physiological disorder such as iron deficiency, though typical iron deficiency is interveinal chlorosis of new growth, which is somewhat different from WT symptoms. In addition, an iron sup-

Corresponding author: Y. Takikawa

E-mail: abytaki@agr.shizuoka.ac.jp

The sequence reported in this paper has been deposited in the DDBJ database under the accession number AB109218.

Accepted for publication 14 August 2003.

Publication no. D-2003-1009-02R

(C) 2003 The American Phytopathological Society plement had no effect. The disease did not reappear until a new outbreak in 1996, when a bacterium was isolated consistently and the inoculation experiment demonstrated that the bacterium was pathogenic on pea, causing both WT symptoms and typical bacterial blight symptoms simultaneously.

Bacterial blight of pea caused by Pseudomonas syringae pv. pisi has been one of the most important problems of pea cultivation all over the world $(4,21)$. The first record of bacterial blight of pea in Japan was made in 1935, and the disease has been sporadic in occurrence $(23,25,31)$. No mention of WT symptom has been made previously $(4,21)$.

WT symptoms on pea resemble those of apical chlorosis on marigold caused by $P$. syringae pv. tagetis. Our preliminary study indicated that the bacterium isolated from pea belongs to the $P$. syringae group, though it had more similarity with $P$. syringae pv. pisi than with $P$. syringae pv. tagetis in phenotypic and pathogenic characteristics. Therefore, we initiated a study to further characterize the pathogen isolated from WT symptoms and to compare it with known $P$. syringae pathovars. A preliminary report has been made (30). This study provides a full description of this newly emerged bacterium causing WT of pea.

\section{MATERIALS AND METHODS}

Symptoms. WT disease of pea occurs in early spring and early autumn when pea plants grow vigorously (Fig. 1A). In summer and winter, symptoms are hardly observed. The entire apical shoot, including leaflets, stipules, and young pods, is chlorotic (Fig. 1B). Symptoms initially appear as a slight yellowing at the margin of an expanding leaflet while veins and tips of the leaflet remain light green (Fig. 1C). Later, the whole apical shoot becomes light yellow, then white. There is a sharp, delineated boundary between apparently healthy green and symptom-expressing white tissues. As occurs with bacterial blight of pea, WT plants may display extensive water-soaked lesions on stems and on leaflets at the basal part of the infected plant where white discoloration is not observed (Fig. 1D). Water-soaked spots also are observed on chlorotic leaflets and pods (Fig. 1E). As an infected plant continues to grow, newly developed lateral shoots turn yellow to white. On the same affected plant, mature shoots never turn white. Earliest symptoms can be observed on seedlings 2 to 3 weeks after germination (Fig. $1 F)$. The flowers formed on chlorotic shoots have whitish calyxes, but the petals are normal in color (e.g., a red flower). Formed pods are papery and unmarketable. Severely affected plants stop growing and are stunted. During our survey from 1996 to 2000 , we could not observe the plant showing typical bacterial blight symptoms without WT symptoms.

Isolation of pathogen. Bacterial isolates were extracted from affected pea tissues during April to May and late August to October in 1996 to 2000. Small pieces of the plants were excised from chlorotic tissues, the boundary part of green and white tissues without water-soaking, and water-soaked lesions. The pieces were surface sterilized in $70 \%$ ethyl alcohol for $10 \mathrm{~s}$, macerated in $100 \mu \mathrm{l}$ distilled water, and streaked onto yeast-peptone agar 
(YPA; yeast extract, $5 \mathrm{~g}$; peptone, $10 \mathrm{~g}$; agar, $15 \mathrm{~g}$; distilled water, $1,000 \mathrm{ml} ; \mathrm{pH}$ 6.8) plates. The plates were incubated for 2 to 3 days at $27^{\circ} \mathrm{C}$. Single colonies were subcultured on slants of potato peptoneglucose agar (PPGA; infusion from $200 \mathrm{~g}$ of potato; peptone, $5 \mathrm{~g}$; glucose, $5 \mathrm{~g}$; $\mathrm{Na}_{2} \mathrm{HPO}_{4} \cdot 12 \mathrm{H}_{2} \mathrm{O}, 3 \mathrm{~g} ; \mathrm{KH}_{2} \mathrm{PO}_{4}, 0.5 \mathrm{~g}$; $\mathrm{NaCl}, 3 \mathrm{~g}$; agar, $15 \mathrm{~g}$; distilled water, 1,000 ml) medium. The cultured bacterial cells were suspended in $10 \%$ skim milk with $1.5 \%$ sodium glutamate and stored at $-20^{\circ} \mathrm{C}$. The skim milk suspensions also were lyophilized for long-term storage.

Bacteriological characterization. Thirtyfour bacterial isolates were extracted from pea plat showing WT symptoms and were tested for bacteriological properties. For comparison, 16 strains of $P$. syringae pv. pisi and one each of strains of $P$. syringae pv. syringae, pv. phaseolicola, pv. maculicola, and pv. coronafaciens were included. Nine strains of an unidentified pathovar of
P. syringae from water-soaked lesions on pea stems also were included for identification (Table 1). Phenotypic properties divided the sixteen strains of $P$. syringae pv. pisi into two groups, A (PP1, 8, 11, 13, 18, 28, 35, saya2, kuki1, and kuki5) and B (Pisum94-1, 94-2, 94-3, 94-4, MAFF311141, and 311144). Nine strains of an unidentified pathovar of $P$. syringae from pea plant formed another group, designated as $P$. syringae group $\mathrm{C}$.

Colony morphology was observed on a YPA plate. Gram reaction was determined by a nonstaining method (28). Flagella were stained with $2 \%$ potassium phosphotungstate and observed with an electron microscope. Accumulation of poly- $\beta$-hydroxybutyrate (PHB) was determined by Pierce and Schroth's method (26). Fluorescent pigment production was determined on medium B of King et al. (19). An oxidation/fermentation (OF) test was carried out in the medium of Hugh and Leifson (18).
In a test for indole production, bacteria were grown in peptone water and indole was detected with Kovac's reagent (13). Urease activity was determined on Christensen's urea agar plates (7). Phenylalanine deaminase activity was determined on the medium of Ewing et al. (11). Tests for hydrolysis of starch and casein digestion were performed as described in the Manual of Methods for General Bacteriology (13). For $\mathrm{H}_{2} \mathrm{~S}$ production, cultures were grown in peptone water and $\mathrm{H}_{2} \mathrm{~S}$ was tested using lead-acetate paper. Growth at $40^{\circ} \mathrm{C}$ was examined in peptone water. Reducing substances from sucrose and reaction in purple milk were tested by the methods described by Dye (10). Utilization of organic compounds as sole sources of carbon was determined using the modified medium of Ayers et al. (29), incorporating carbohydrates at $0.2 \%$ and the other compounds at $0.1 \%$. A positive reaction was recorded when visible growth was observed. The

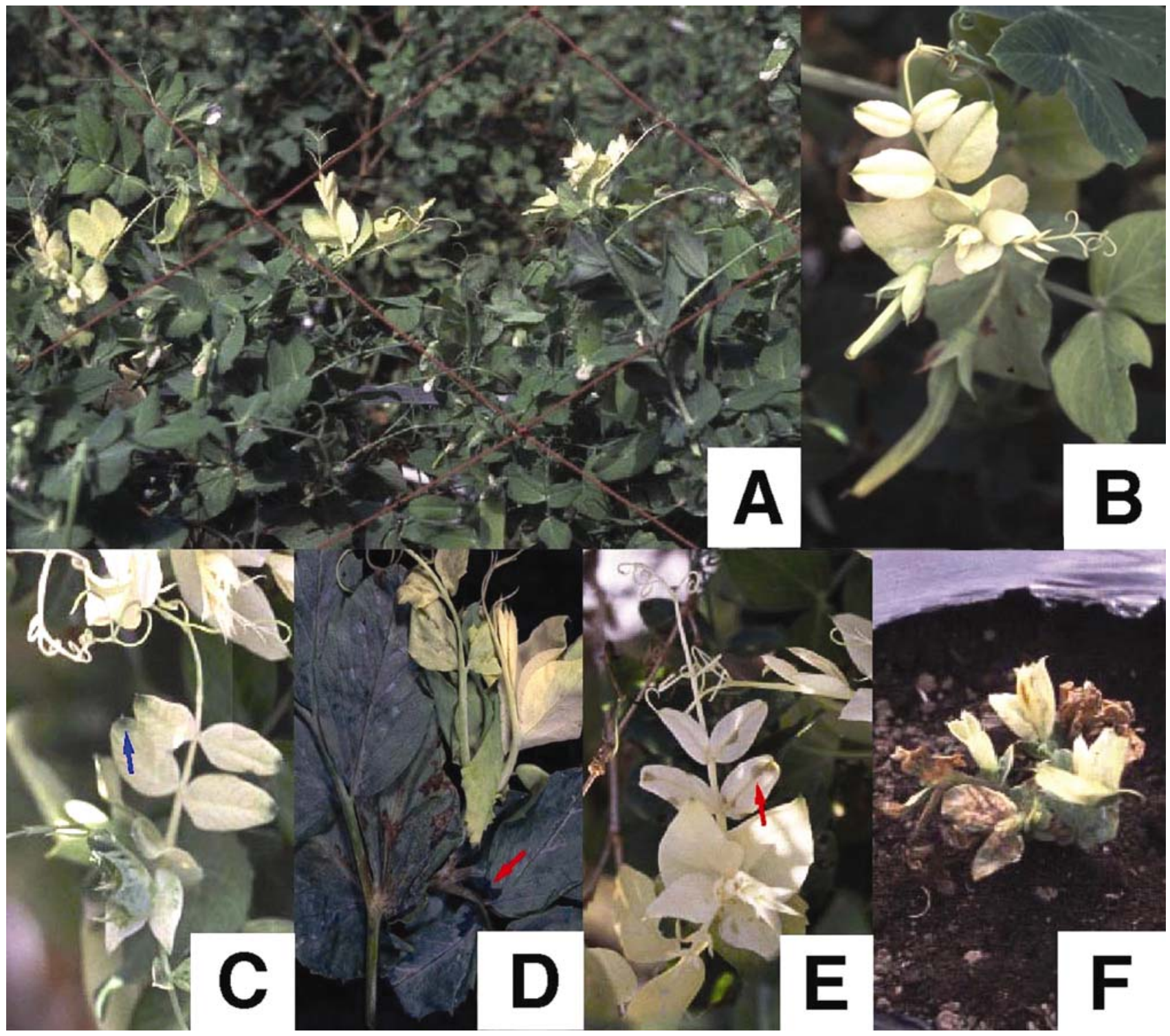

Fig. 1. Natural symptoms. A, Pea plants showing white top (WT) symptoms in the field. B, Typical WT symptoms on an apical shoot. C, Green veins on white leaflets (blue arrow). D, WT symptoms associated with water-soaked lesions (red arrow). E, Water-soaked spots on white leaflets (red arrow). F, WT symptoms on young pea seedlings. 
followings tests were performed according to the methods described by Lelliott et al. (22): levan production, oxidase activity, potato soft rot, arginine dihydrolase, and tobacco hypersensitive reaction (LOPAT); nitrate reduction; tyrosinase activity; proesculin, arbutin, and Tween 80; gelatin cept when stated otherwise, bacterial strains were cultivated at $25^{\circ} \mathrm{C}$ in all tests.

Pathogenicity tests. Pathogenicity tests were performed on 2-week-old pea seedlings (cv. Izu-ichigou and Kelvedon Wonder) in the greenhouse at various seasons throughout the year. Seeds were germiwere transplanted into pots $8.0 \mathrm{~cm}$ in diameter. Culture (1 to 2 days old) on PPGA was scraped and suspended in sterile water at a concentration of approximately $1 \times 10^{8}$ $\mathrm{CFU} / \mathrm{ml}$ and used as inoculum. For stab inoculation, stems, stipules, and leaflets were stabbed with a needle and a 10- $\mu$ l droplet of bacterial suspension was placed over the wounded site. For spray inoculations, bacterial suspensions were sprayed using perfume misters with a 20 -ml plastic bottle. In both inoculation experiments, sterile water was used as a control. Sprayed plants were kept humid overnight by holding them in a mist chamber and, subsequently, kept in a greenhouse.

Each strain also was inoculated to three detached pea pods placed in a $9-\mathrm{cm}$ petri dish containing a filter paper sterilized by autoclaving. The pods were stabbed with a needle through bacterial suspension put on the pod surface. After inoculation, the filter paper was moistened with sterile distilled water and incubated at $27^{\circ} \mathrm{C}$ in a dark duction of 2-keto-gluconate; hydrolysis of liquefaction; and lecithinase activity. Exnated in beds and 1-week-old seedlings

chamber for 7 days. The host range of the pathogen was tested by stab inoculation on the following plants: Actinidia chinensis (kiwi), Arachis hypogaea (peanut), Brassica oleracea var. capitata (cabbage), $\mathrm{Ca}$ mellia sinensis (tea), Capsicum annuum (green pepper), Citrullus lanatus (watermelon), Citrus natsudaidai (natsudaidai), Cucumis sativus (cucumber), Eriobotrya japonica (loquat), Glycine max (soybean), Iris $\times$ germanica (flag iris), Lycopersicon esculentum (tomato), Morus bombycis (mulberry), Myrica rubra (Chinese bayberry), Nicotiana tabacum (tobacco), Oryza sativa (rice), Phaseolus vulgaris (kidney bean), Photinia glabra (Japanese photinia), Prunus mume (Japanese apricot), Prunus persica (peach), Syringa vulgaris (lilac), Tagetes erecta (marigold), Trifolium repens (white clover), Triticum aestivum (wheat), Vicia faba (broad bean), and Zinnia elegans (zinnia). Annual seed plants were grown in pots in the greenhouse and were inoculated at the three- to five-trueleaf stage. Field-grown perennial trees and shrubs were inoculated on suckling shoots and leaves. Controls received the same treatment without bacterial cells. Plants were evaluated for any symptoms up to 1 month after inoculation.

16S ribosomal DNA sequence. Total bacterial genomic DNA was isolated by the miniscale cetyltrimethyl ammonium bromide (CTAB) purification method as described by Ausubel et al. (2). The nearly complete 16S ribosomal (r)DNA sequence of the WT strain PP105 was obtained by amplification of the genomic DNA with primers 27f (5'-AGAGTTTGATCMTGGCTCAG-3') and 1492r (5'-TACGGYTACCTTGTTACGACTT-3') (20). Se-

Table 1. Bacterial strains used in this study

\begin{tabular}{|c|c|c|c|c|}
\hline $\begin{array}{l}\text { Strains } \\
\text { Stro }\end{array}$ & SUPP no. $^{\mathrm{a}}$ & Year & Group & Source \\
\hline \multicolumn{5}{|l|}{ White top isolates } \\
\hline $\begin{array}{l}\text { PP101, 102, 103, 104, 105, 106, 107, 108, } \\
\quad 109\end{array}$ & $1658-1666$ & 1996 & WT & This study \\
\hline $\begin{array}{l}\text { Pisum97-1, 97-2, 97-3, 97-4, 97-5, 97-6, } \\
\text { 97-8, 97-91 }\end{array}$ & $1700-1707$ & 1997 & WT & This study \\
\hline Pip1, 2, 3, 4, 5, 9 & & 1998 & WT & This study \\
\hline Pip $13,14,15,16,17$ & & 1999 & WT & This study \\
\hline Pip18, 19, 20, 21, 22, 23 & & 2000 & WT & This study \\
\hline \multicolumn{5}{|l|}{ Pseudomonas syringae pv. pisi } \\
\hline $\mathrm{PP} 1,8,11,13,18,28,35$ & $1667-1673$ & 1978 & A & Ohta (25) \\
\hline saya2, kuki1, kuki5 & $1999-2001$ & 1980 & A & SUPP \\
\hline Pisum94-1, 94-2, 94-3, 94-4 & $1696-1699$ & 1994 & B & SUPP \\
\hline MAFF311141, 311144 & $1945-1946$ & 1994 & B & $\mathrm{MAFF}^{\mathrm{b}}$ \\
\hline \multicolumn{5}{|l|}{ Pseudomonas syringae from pea } \\
\hline Pisum-1 & 679 & 1984 & $\mathrm{C}$ & SUPP \\
\hline Pea8504, 8506, 8512 & $1736-1738$ & 1985 & $\mathrm{C}$ & SUPP \\
\hline $\mathrm{E} 3,7,13,14,17$ & $1739-1743$ & 1985 & $\mathrm{C}$ & SUPP \\
\hline \multicolumn{5}{|l|}{ P. syringae pv. syringae (Lilac) } \\
\hline LOB2-1 & 458 & & & SUPP \\
\hline \multicolumn{5}{|l|}{ P. syringae pv. phaseolicola (Kidney been) } \\
\hline $\mathrm{BQH} 1$ & 1139 & & & SUPP \\
\hline \multicolumn{5}{|l|}{ P. syringae pv. maculicola (Turnip) } \\
\hline PMC 8301 & 2206 & & & SUPP \\
\hline \multicolumn{5}{|l|}{ P. syringae pv. coronafaciens (Oat) } \\
\hline AVPCO8101 & 196 & & & SUPP \\
\hline
\end{tabular}

\footnotetext{
${ }^{a}$ All strains were preserved in the culture collection of Shizuoka University Plant Pathology (SUPP).
}

${ }^{b}$ From MAFF (Ministry of Agriculture, Forestry and Fishery, Japan) see reference 23. quencing reactions were performed using a SequiTherm EXCEL II-LC DNA Sequencing Kit (Epicentre Technologies, Madison, WI) as recommended by the manufacturer. Sequencing reactions were electrophoresed using a 4000L DNA sequencer (LI-COR, Lincoln, NE). A similarity search with the $16 \mathrm{~S}$ rDNA sequence was performed against 16S rDNA sequences available in the DDBJ/EMBL/GenBank databases using the FASTA. The accession number for the nearly complete $16 \mathrm{~S}$ rDNA sequence of PP105 is AB109218.

Repetitive sequence based-polymerase chain reaction (rep-PCR). The rep-PCR was carried out as described by Rademaker et al. (27) with some modifications. Three sets of primers were tested; these were based on the enterobacterial repetitive intergenic consensus (ERIC) sequence (ERIC 1R [5'-ATGTAAGCTCCTGGGGATTCAC] and ERIC 2 [5'-AAGTAAGTGACTGGGGTGAGCG]), and on the repetitive extragenic palindromic (REP) element (REP 1R [5'-IIIICGICGICATCIGGC] and REP 2I [5'-ICGICTTATCIGGCCTAC]), and on the 154-bp BOX element (BOX A1R [5'-CTACGGCAAGGCGACGATGACG]). We carried out the PCR reactions in the following mixture (total, $10 \mu \mathrm{l}$ ): 1× Gitschier buffer (16.6 $\mathrm{mM}\left(\mathrm{NH}_{4}\right)_{2} \mathrm{SO}_{4}, 67 \mathrm{mM}$ Tris-HCl, $\mathrm{pH}$ 8.8, $6.7 \mathrm{mM} \mathrm{MgCl}$, $6.7 \mathrm{mM}$ EDTA, $30 \mathrm{mM} \beta$ mercaptoethanol), $4 \mu \mathrm{g}$ of bovine serum albumin, $10 \%$ dimethyl sulfoxide ( $\mathrm{vol} / \mathrm{vol}$ ), 50 pmoles of each primer, $0.2 \mathrm{mM}$ each dNTP, 1 unit of Taq polymerase (Gene Taq, Nippon Gene, Japan), and 10 ng of bacterial genomic DNA. Each reaction set included a negative control containing water instead of the DNA template. The samples were amplified through 1 cycle at $95^{\circ} \mathrm{C}$ for $7 \mathrm{~min} ; 30$ cycles at $94^{\circ} \mathrm{C}$ for $1 \mathrm{~min} ; 52^{\circ} \mathrm{C}$ (ERIC), $40^{\circ} \mathrm{C}(\mathrm{REP})$, or $53^{\circ} \mathrm{C}(\mathrm{BOX})$ for 1 $\mathrm{min}$; and $65^{\circ} \mathrm{C}$ for $8 \mathrm{~min}$, followed by $65^{\circ} \mathrm{C}$ for $16 \mathrm{~min}$ in a GeneAmp PCR System 2400 (Perkin-Elmer Cetus, Norwalk, CT). PCR products were separated by electrophoresis in $1.5 \%$ agarose gel at $70 \mathrm{~V}$ for $40 \mathrm{~min}$ in $1 \times$ Tris-acetate-EDTA buffer. Gels were stained with ethidium bromide and differences in DNA fingerprint patterns were assessed visually.

\section{RESULTS}

Bacterial isolation and characterization. When we attempted to isolate bacteria from chlorotic tissues, they gave no bacterial growth. Large numbers of bacteria consistently were isolated from watersoaked lesions or the boundary part of green and white tissues without water soaking. Among the 34 isolates from plants with WT symptoms, 8 (Pip9, 14, 15, 17, $18,19,20$, and 21) were isolated from the boundary of white and green tissues without water-soaked lesions and 26 were from classical water-soaked lesions. Later, they were revealed to be identical in almost all properties, including pathogenicity; there- 
fore, they were collectively referred to as WT isolates. They were subjected to bacteriological tests together with $16 P$. syringae pv. pisi strains $\left(\begin{array}{lll}10 & P \text {. syringae pv. pisi }\end{array}\right.$ group A and $6 P$. syringae pv. pisi group B), 4 strains of $P$. syringae pathovars, and 9 unidentified strains from pea ( $P$. syringae group C).

The colonies of all isolates and reference strains studied were grayish white and butyrous, 1 to $2 \mathrm{~mm}$ in diameter on YPA after 3 days at $27^{\circ} \mathrm{C}$, with an entire margin, circular and convex. They were gramnegative, aerobic, non-sporing, straight rods, and motile by means of 1 to 6 polar flagella. PHB granules were not accumulated. In LOPAT tests, all isolates and reference strains were positive for levan production and tobacco hypersensitive reaction, but negative for oxidase, arginine dihydrolase, and potato soft rot. WT isolates and the $P$. syringae pv. pisi group A strains did not produce fluorescent pigment on King's B medium, but $P$. syringae pv. pisi group $\mathrm{B}, P$. syringae group $\mathrm{C}$, and four other pathovars did. All WT isolates and $P$. syringae pv. pisi strains gave positive reactions in the following tests: oxidative metabolism of glucose, reducing substances from sucrose, and catalase and Tween 80 hydrolysis. In purple milk reaction, WT isolates, $P$. syringae pv. pisi group A, and $P$. syringae group $\mathrm{C}$ showed digestion and alkali production. All WT isolates and reference strains gave negative reactions in the following tests: lecithinase and phenylalanine deaminase, $\mathrm{H}_{2} \mathrm{~S}$ production, indole production, growth at $40^{\circ} \mathrm{C}$, nitrate reduction, and starch hydrolysis. WT isolates and $P$. syringae pv. pisi groups $\mathrm{A}$ and B utilized glucose, galactose, fructose, mannose, sucrose, xylose, ribose, glycerol, mannitol, sorbitol, inositol, acetate, citrate, gluconate, glycerate, meso-tartrare, glutarate, L-malate, succinate, quinate, saccharate, caprate, peralgonate, $p$-hydroxybenzonate, $\gamma$-aminobutyrate, L-arginine, Lserine, L-leucine, triacetin, sarcosine, and trigonelline. They did not utilize Darabinose, lactose, maltose, melibiose, melezitose, L-rhamnose, cellobiose, trehalose, adonitol, dulcitol, starch, salicin, $\alpha-$ methyl-D-glucoside, D-tartrate, L-tartrate, formate, n-butyrate, propionate, mesaconate, sebacate, anthranilate, linolenate, $\beta$ alanine, L-valine, L-isoleucine, and tyrosine. WT isolates and $P$. syringae pv. pisi groups A and B utilized homoserine. $P$. syringae pv. pisi group B showed negative reactions on esculin and arbutin hydrolysis, casein digestion, gelatin liquefaction, and alkali production and digestion in purple milk, and did not utilize erythritol, DLlactate, and betain, whereas WT isolates and $P$. syringae pv. pisi group A showed positive reactions in these tests. $P$. syringae group $\mathrm{C}$ did not utilize homoserine but utilized D-tartrate. The WT isolates were homologous in these tests except for brown pigment production. In all, $21 \mathrm{WT}$ isolates,
PP105, 106, 107, 109, Pip1 to 5, 9, and 13 to 23 , produced diffusible brown pigment on many media, including YPA and King's $\mathrm{B}$ medium, whereas 13 WT isolates, PP101 to 104, PP108, and Pisum97-1 through 9791 , did not. $P$. syringae group $\mathrm{C}$ was indistinguishable from the pv. syringae strain except for positive utilization of D-tartrate. WT isolates were clearly distinguished from pvs. phaseolicola, maculicola, and coronafaciens in the properties shown in Table 2.

Pathogenicity tests. Despite the difference of the position of isolation, all of the WT isolates behaved equally in pathogenicity tests on pea. Through stab inoculation on stems, WT isolates initially produced symptoms only around the wounds in the form of dark, water-soaked elliptical areas about 4 days after inoculation. WT isolates produced distinctive fan-like, water-soaked spots along the veins on stipules and leaflets which were similar to classical bacterial blight symptoms (Fig. 2A). As the plant inoculated with WT isolates grew, newly expanding leaves became yellow 1 week after inoculation (Fig. 2B). Apical shoots became chlorotic to whitish in the following week (Fig. 2C). Later, lateral shoots also became white (Fig. 2D). The WT plant showed remarkable stunting (Fig. 2E). P. syringae pv. pisi group A and
B strains also caused typical bacterial blight symptoms but the inoculated pea plants never produced WT symptoms. When $P$. syringae group $\mathrm{C}$ strains were inoculated, water-soaked lesions were formed at the inoculation sites on stem and leaflet about 4 days after inoculation, and they developed into brown necrosis.

When inoculations were made in midsummer and midwinter, WT isolates and $P$. syringae pv. pisi groups A and B produced leaf spot and blight, and did not cause chlorosis. When pea plants inoculated with WT isolates were kept under shade, WT symptoms hardly appeared, indicating the requirement of light for the symptom development.

By spray inoculations, all WT isolates and $P$. syringae $\mathrm{pv}$. pisi group $\mathrm{A}$ and $\mathrm{B}$ strains produced small, shiny, water-soaked spots on leaflets and stems. Within a few days, these spots developed into irregularly shaped lesions on leaflets or dark-green elliptical lesions on stems, invading stipules. Spray-inoculated plants did not develop WT symptoms if stems or stipules were not wounded.

When inoculated on mature pods, WT isolates and $P$. syringae pv. pisi group A and B strains produced a dark, watersoaked spot that later turned brown, sunken, and surrounded by a narrow, wa-

Table 2. Major bacteriological properties of Pseudomonas syringae strains isolated from pea in comparison with related pathovars

\begin{tabular}{|c|c|c|c|c|c|c|c|c|}
\hline \multirow[b]{2}{*}{ Tests } & \multicolumn{8}{|c|}{ Strains $^{\mathbf{a}}$} \\
\hline & WT & Ppi (A) & Ppi (B) & Ps (C) & Pss & Psp & Psm & Psc \\
\hline Gram reaction & $-\mathrm{b}$ & - & - & - & - & - & - & - \\
\hline OF test & $\mathrm{O}$ & $\mathrm{O}$ & $\mathrm{O}$ & $\mathrm{O}$ & $\mathrm{O}$ & $\mathrm{O}$ & $\mathrm{O}$ & $\mathrm{O}$ \\
\hline PHB accumulation & - & - & - & - & - & - & - & - \\
\hline Growth at $40^{\circ} \mathrm{C}$ & - & - & - & - & - & - & - & - \\
\hline Fluorescent pigment & - & - & + & + & + & + & + & + \\
\hline Gelatin liquefaction & + & + & - & + & + & - & - & + \\
\hline Esculin hydrolysis & + & + & - & + & + & - & - & + \\
\hline Purple milk reaction & $\mathrm{KD}$ & $\mathrm{KD}$ & - & KD & $\mathrm{KD}$ & - & - & KD \\
\hline Levan & + & + & + & + & + & + & + & + \\
\hline Oxidase & - & - & - & - & - & - & - & - \\
\hline Potato soft rot & - & - & - & - & - & - & - & - \\
\hline Arginine dihydrolase & - & - & - & - & - & - & - & - \\
\hline Tobacco HR & + & + & + & + & + & + & + & + \\
\hline \multicolumn{9}{|l|}{ Reducing substances } \\
\hline from sucrose & + & + & + & + & + & + & + & + \\
\hline Nitrate reduction & - & - & - & - & - & - & - & - \\
\hline \multicolumn{9}{|l|}{ Utilization of } \\
\hline Sucrose & + & + & + & + & + & + & + & + \\
\hline Trehalose & - & - & - & - & - & - & - & - \\
\hline Erythritol & + & + & - & + & + & - & - & + \\
\hline Inositol & + & + & + & + & + & - & + & + \\
\hline Sorbitol & + & + & + & + & + & - & + & + \\
\hline D-Tartrate & - & - & - & + & - & - & + & - \\
\hline L-Tartrate & - & - & - & - & - & - & - & - \\
\hline DL-Lactate & + & + & - & + & + & - & + & - \\
\hline$\beta$-Alanine & - & - & - & - & - & - & - & - \\
\hline Valine & - & - & - & - & - & - & - & - \\
\hline Betaine & + & + & - & + & + & + & + & + \\
\hline Homoserine & + & + & + & - & - & - & - & - \\
\hline
\end{tabular}

a Abbreviations for strains: WT $=$ White top isolates; Ppi $(\mathrm{A})$ and $(\mathrm{B})=$ P. syringae pv. pisi groups A and B; Ps $(\mathrm{C})=P$. syringae from pea; Pss $=$ P. syringae pv. syringae $;$ Psp $=P$. syringae pv. phaseolicola $; \mathrm{Psm}=P$. syringae pv. maculicola $;$ and $\mathrm{Psc}=P$. syringae pv. coronafaciens.

$\mathrm{b}+=$ positive reaction; $-=$ negative reaction; $\mathrm{O}=$ oxidative metabolism of glucose; $\mathrm{D}=$ digestion; and $\mathrm{K}=$ alkali production. 
ter-soaked zone 0.4 to $0.7 \mathrm{~cm}$ in diameter about 1 week after inoculation. $P$. syringae group $\mathrm{C}$ developed dry and brown spots at the inoculation site. None of the strains developed chlorosis with pod inoculation. One WT isolate, PP105, was selected for determination of its host range. The isolate was not pathogenic on any other plants tested, except zinnia. When PP105 was inoculated at the hypocotyls of a zinnia seedling, the youngest leaf showed mild chlorotic after 7 days but recovered 4 to 5 days later without induction of any watersoaked symptoms. Necrotic lesions were induced when $P$. syringae group $\mathrm{C}$ strains were inoculated onto young shoots of peach.

$16 S$ rDNA sequence. The $16 \mathrm{~S}$ rDNA sequence $(1,477 \mathrm{bp})$ of WT isolate PP105 was determined. The most closely related sequence in databases by FASTA analysis was $P$. syringe pv. syringae (Z76669), with $99.8 \%$ identity over 1,400 bases. 16S rDNA sequences of other known $P$. syringae showed similarities of 99.1 to $99.7 \%$.

rep-PCR. Genomic fingerprints were generated for the tested bacteria. Data from three primer sets were scored visually, taking differences of the presence or absence of major bands into account. More than 20 DNA fragments, ranging from 0.2 to $6.0 \mathrm{~kb}$ in size, were amplified with ERIC-, BOX-, and REP-PCR primers. Based on genomic fingerprints using ERIC primers, two distinct groups were identified for WT isolates and $P$. syringae pv. pisi strains. They were arbitrarily designated as PCR type I and II. Type I contained WT isolates and $P$. syringae pv. pisi group A strains (Table 1 and Fig. 3, lane 1 to 11). Type II consisted of $P$. syringae pv. pisi group B strains (Table 1 and Fig. 3, lanes 12 and 13). Type I exhibited some unique bands compared with type II, such as bands of approximately 500 and $200 \mathrm{bp}$ bands in ERIC-PCR (Fig. 3), whereas type II produced bands of approximately 600 and $100 \mathrm{bp}$. WT isolates and $P$. syringae pv. pisi group A strains produced the same fingerprints in BOX- and REP-PCR as well as in ERIC-PCR (data not shown). The reference strains and $P$. syringae group C strains differed from either type I or II fingerprints in all primer sets.

\section{DISCUSSION}

Although the disease which has occurred in Japan since 1996 has similarities with

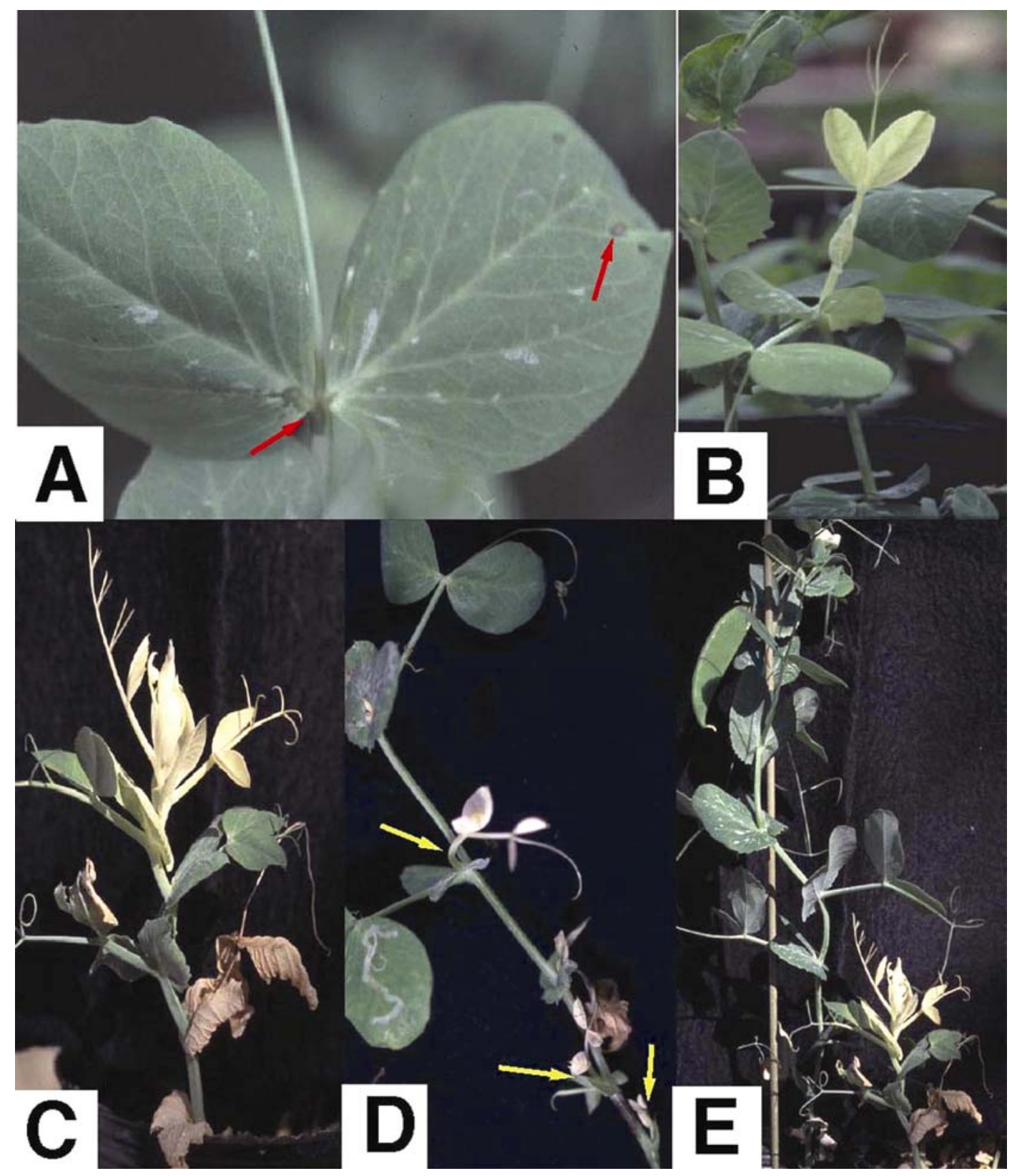

Fig. 2. Symptom expression by artificial inoculation. A, Water-soaked spots on leaflets (red arrows) 4 days after inoculation. B, Chlorotic symptoms on apical shoot 1 week after inoculation. C, White top (WT) symptoms on apical shoot 2 weeks after inoculation. D, WT symptoms on lateral shoot (yellow arrows) 2 weeks after inoculation. E, Stunting of inoculated plant compared with healthy one. 
the symptoms of classical bacterial blight of pea, it is characterized by chlorotic and whitening of the apical shoot, including leaf, stipule, and pod. We propose that the common name of this disease be called bacterial white top (WT) of pea.

The causal agent of WT of pea is a gram-negative rod, aerobic, non-sporing, and motile, with one to six polar flagella. The pathogen does not accumulate PHB granules, and does not grow at $40^{\circ} \mathrm{C}$. These results indicate the pathogen should be included in the genus Pseudomonas. The pathogen is characterized as levan production positive, oxidase negative, potato soft rot negative, arginine dihydrolase negative, and tobacco hypersensitive reaction positive. Therefore, the pathogen belongs to Group Ia of $P$. syringae (22). The pathogen does not utilize trehalose, $\beta$-alanine, and valine, does not reduce nitrate, utilizes sucrose, and produces reducing substances from sucrose. These characters further support the inclusion of the pathogen in $P$. syringae. Sequence analysis of the $16 \mathrm{~S}$ rDNA of a WT isolate clearly indicates that it is a member of $P$. syringae.

Several studies have shown that $P$. syringae pv. pisi is heterogeneous in terms of phenotypic and genetic properties $(1,14)$. Grondeau et al. reported that most strains produced fluorescence, did not hydrolyze esculin, and did not utilize DL-lactate, whereas aberrant strains showed opposite results in these tests. The characteristics of WT and $P$. syringae pv. pisi group A strains coincide with the latter, and $P$. syringae pv. pisi group B strains coincide with the former. All of the WT isolates and P. syringae pv. pisi groups A and B can utilize homoserine, utilization of which is one of the characteristics of pv. pisi (16).

By inoculation, the WT isolates first produced water-soaked lesions indistinguishable from the typical symptom of bacterial blight; and, later, they caused the typical WT symptoms after 14 days. $P$. syringae pv. pisi group $\mathrm{A}$ and $\mathrm{B}$ strains produced dark, water-soaked spots, and $P$. syringae group $\mathrm{C}$ strains developed dry and brown spots on inoculation sites. $P$. syringae pv. pisi groups A and B and P. syringae group $\mathrm{C}$ never developed WT symptoms. On pod inoculation, all of the strains caused dark-brown, sunken spots, but not WT symptoms. In spray inoculation, uninjured plants did not develop WT symptoms. We speculate that the WT pathogen can infect from wounded areas and can affect the growing point, but cannot cause WT in mature tissues. WT and $P$. syringae pv. pisi group $\mathrm{A}$ and $\mathrm{B}$ strains were not pathogenic on other plants. P. syringae group $\mathrm{C}$ strains produced necrosis on young peach twig. Our preliminary examination detected a part of syringomycin synthetase genes in the genome of $P$. syringae group $\mathrm{C}$ strains by Southern hybridization. Therefore, $P$. syringae group $\mathrm{C}$ strains were identified as $P$. syringae pv. syringae, the cause of brown spot disease of pea (21).

Specific genomic fingerprints generated with rep-PCR are an effective taxonomic tool that is able to identify pathovars and strains of phytopathogenic bacteria $(17,27,36)$. The use of three rep-PCR methods (ERIC-, BOX-, and REP-PCR) enabled us to distinguish genomic variation among WT isolates and $P$. syringae pv. pisi strains. WT isolates and $P$. syringae pv. pisi group A strains gave the same fingerprints in all primer sets. $P$. syringae pv. pisi group B strains gave significant differences. repPCR also could be used to distinguish pv. pisi from other $P$. syringae pathovars.

All of the above-mentioned results indicated that the pathogen of WT was identical with $P$. syringae pv. pisi group A strains expect for symptom expression. Therefore, we concluded that the WT isolates should be included in pv. pisi as a distinct strain. Our results confirmed the diversity of $P$. syringae pv. pisi. WT strains and $P$. syringae pv. pisi group strains never were isolated in a single plant or a field.

WT symptoms were observed in early spring and early autumn. Increased WT incidence sometimes was observed after passage of a typhoon. Damage caused by typhoons may be involved with increased WT development, confirming the need for wounding in experiments. In addition, the pea plants were damaged by heavy frost and had warm rain 10 days before the appearance of WT symptoms in February. Development of bacterial blight is known to depend largely on weather. Infection and spread are favored by wet and cold conditions, and disease spreads during the growing season, being dispersed from plant to plant mainly by wind-driven rain $(34,35)$. It is inferred that development of WT could occur in a similar way. Bacterial blight of pea caused by $P$. syringae pv. pisi is seedborne. Field observations indicate that seeds from affected plants tend to show the WT symptom at small seedling stage. It is suggested that the WT pathogen also is capable of seed transmission. Infected plant debris also may carry the pathogen. The disease may be controlled by the same methods used for bacterial blight (21).

The effect of environmental conditions such as light and temperature also was suggested. In inoculation experiments under shade conditions, faint chlorotic symptoms appeared after about 3 weeks, much later than under normal lighting conditions. In midsummer and midwinter, inoculated plants developed typical bacterial blight symptoms, but rarely become yellow or white. Some $P$. syringae pathovars produce phytotoxins which are involved in the development of symptoms such as halo and chlorosis (24). Toxin production and symptom development have been reported to depend on temperature and sunlight $(6,8,9)$.

As mentioned above, the pathogenic bacterium could not be isolated from the chlorotic tissues but could be isolated from the lesions, which were indistinguishable from the classical blight symptoms. Therefore, we speculated that WT strains may produce toxin-like substances or some other chlorosis-inducing factors which may translocate from the water-soaked lesion to the apical shoot. $P$. syringae pv. pisi group $A$ and $B$ strains may not have such activities. A similar occurrence has been reported for $P$. syringae pv. tabaci and " $P$. angulata". At first, the two tobacco pathogens were given independent names based on their symptom expressions. Later, the

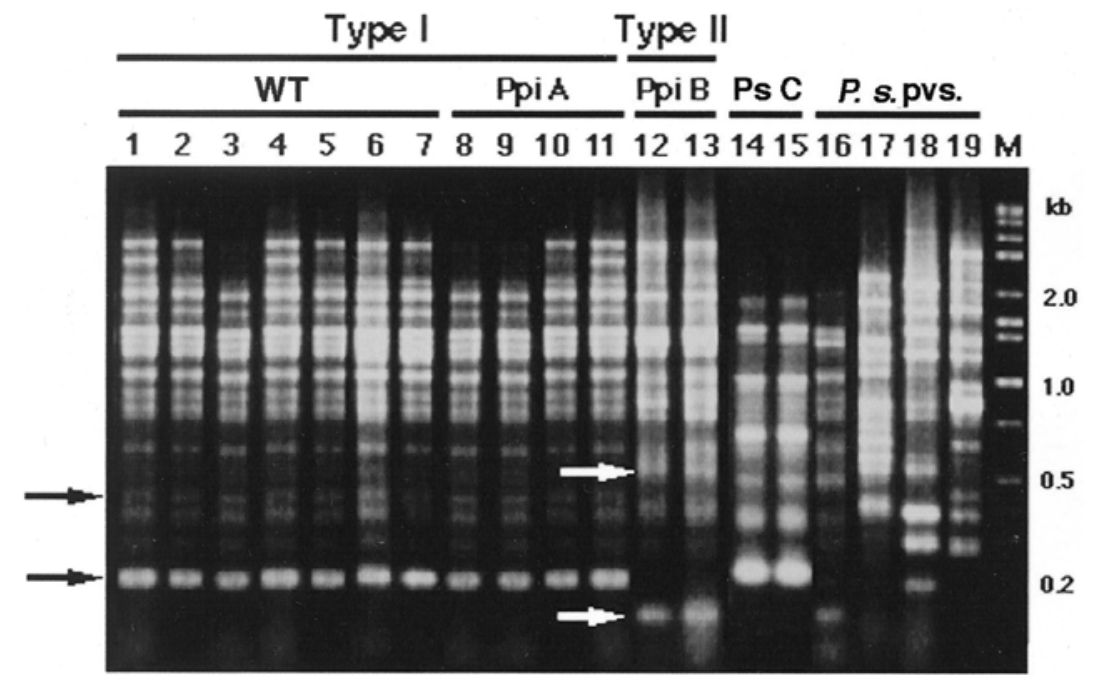

Fig. 3. Repetitive sequence based-polymerase chain reaction (rep-PCR) fingerprints obtained from Pseudomonas syringae pv. pisi (Ppi) strains and closely related pathovars with the enterobacterial repetitive intergenic consensus (ERIC) primers. Arrows indicate specific bands in each polymorphic types. M, DNA size marker; lanes 1 to 7, white top (WT) strains; lanes 8 to 11, Ppi group A strains; lanes 12 to 13, Ppi group B strains; lanes 14 to 15, P. syringae (Ps) group C strains; lanes 16 to 19, $P$. syringae pv. syringae, pv. phaseolicola, pv. maculicola, and pv. coronafaciens, respectively. 
two pathogens were proved to be identical in bacteriological properties and host ranges. The differences in symptom expression was attributed to tabtoxin production, which is lost easily during cultivation of $P$. syringae pv. tabaci (33). Therefore, " $P$. angulata" was considered to be a nontoxigenic variety of $P$. syringae pv. tabaci $(3,5)$. During our experiments, a spontaneous mutant of a WT isolate has been obtained by subculturing and causes watersoaked lesions without WT symptoms expression (data not shown). It is impossible to distinguish this mutant from $P$. syringae pv. pisi group A strains in any of its bacteriological properties, PCR fingerprints, or symptom expression on pea plant. We consider that it would be better not to place WT strain in a new pathovar.

Apical chlorosis of marigold incited by $P$. syringae pv. tagetis resembles WT in symptom expression, although pv. tagetis (TAG) differs from WT strains in bacteriological properties such as levan production (WT+, TAG-); gelatin liquefaction (WT+, TAG-); utilization of sucrose, DL-lactate, and erythritol (WT+, TAG-); and utilization of D-tartarate and ethanol (WT-, TAG+) and in host ranges (15,32); and belonging to a genomic group different from P. syringae pv. pisi (12). P. syringae pv. tagetis is not reported in Japan. Thus, we conclude that the WT strain is distinct from $P$. syringae pv. tagetis. There still remains some possibility that the WT strains and $P$. syringae pv. tagetis share a similar mechanism of symptom expression. Analysis of toxin production and its genetic background is underway.

\section{ACKNOWLEDGMENTS}

We thank J. M. Young for helping us in reference search, and D. Shimazaki and M. Torisawa for assistance in sample collection.

\section{LITERATURE CITED}

1. Arnold, D. L., Athey-Pollard, A., Gibbon, M. J., Taylor, J. D., and Vivian, A. 1996. Specific oligonucleotide primers for the identification of Pseudomonas syringae pv. pisi yield one of two possible DNA fragments by PCR amplification: evidence for phylogenetic divergence. Physiol. Mol. Plant Pathol. 49:233-245.

2. Ausubel, F. M., Brent, R., Kingston, R. E., Moore, D. D. Seidman, J. G., Smith, J. A., and Struhl, K. 1987. Current Protocols in Molecular Biology. Wiley-Interscience, New York.

3. Bradbury, J. F. 1967. Pseudomonas tabaci. C. M. I. Descriptions of Pathogenic Fungi and Bacteria. No. 129. CAB International, Slough, UK

4. Bradbury, J. F. 1986. Pseudomonas syringae pv. pisi. Page 171 in: Guide to Plant Pathogenic Bacteria. CAB International, Slough, UK.
5. Bradbury, J. F. 1986. Pseudomonas syringae pv. tabaci. Pages 177-178 in: Guide to Plant Pathogenic Bacteria. CAB International, Slough, UK

6. Budde, I. P., and Ullrich, M. S. 2000. Interactions of Pseudomonas syringae pv. glycinea with host and nonhost plants in relation to temperature and phytotoxin synthesis. Mol. Plant-Microbe Interact. 13:951-961.

7. Christensen, W. S. 1964. Urea decomposition as a means of differentiating proteus and paracolon cultures from each other and from Salmonella and Shigella types. J. Bacteriol. 52:461-466.

8. Confer, B. M., and Youmans, J. 1979. Effect of irradiance upon the population of Pseudomonas coronafaciens in leaves and symptom expression of halo blight of rye. Can. J. Microbiol. 25:163-166.

9. Durbin, R. D., and Sinden, S. L. 1967. The effect of light on the symptomatology of oat halo blight. Phytopathology 57:1000-1001.

10. Dye, D. W. 1968. A taxonomic study of the genus Erwinia. N. Z. J. Sci. 11:590-607.

11. Ewing, W. H., Davis, B. R., and Reavis, R. W. 1957. Phenylalanine and malonate media and their use in enteric bacteriology. Public Health Lab. 15:153.

12. Gardan, L., Shafik, H., Belouin, R., Grimont, F., and Grimont, P. A. D. 1999. DNA relatedness among the pathovars of Pseudomonas syringae and description of Pseudomonas tremae sp. nov. and Pseudomonas cannabina sp. nov. (ex Sutic and Dowson 1959). Int. J. Syst. Bacteriol. 49:469-478

13. Gerhardt, P., Murray, R. G. E., Costilow, R. L., Nester, E. W., Wood, W. A. Krieg, N. R., and Phillips, G. B. 1981. Manual of Methods for General Bacteriology. American Society for Microbiology, Washington, D.C.

14. Grondeau, C., Saunier, M., Poutier, F., and Samson, R. 1992. Evaluation of physiological and serological profiles of Pseudomonas syringae pv. pisi for pea blight identification. Plant Pathol. 41:495-505.

15. Hellmers, E. 1955. Bacterial leaf spot of African marigold (Tagetes erecta) caused by Pseudomonas tagetis sp. n. Acta Agric. Scand. 5:185-200.

16. Hildebrand, D. C. 1972 . Tolerance of homoserine by Pseudomonas pisi and implications of in plant resistance. Phytopathology 63:301302.

17. Hollaway, G. J., Gillings, M. R., and Fahy, P. C. 1997. Use of fatty acid profiles and repetitive element polymerase chain reaction (PCR) to assess the genetic diversity of Pseudomonas syringae pv. pisi and Pseudomonas syringe pv. syringae isolated from field pea in Australia. Aust. Plant Pathol. 26:98-108.

18. Hugh, R., and Leifson, E. 1953. The taxonomic significance of fermentative versus oxidative metabolism of carbohydrates by various gram negative bacteria. J. Bacteriol. 66:22-26.

19. King, E. O., Ward, M. K., and Raney, D. E. 1954. Two simple media for the demonstration of pyocyanin and fluorescin. J. Lab. Clin. Med. 44:301-307.

20. Lane, D. J. 1991. 16S/23S rRNA Sequencing. Pages 115-175 in: Nucleic Acid Techniques in Bacterial Systematics. E. Stackebrandt and M.
Goodfellow, eds. John Wiley \& Sons, New York.

21. Lawyer, A. S., and Chun, W. 2001. Bacterial Blight. Pages 22-23 in: Compendium of Pea Diseases and Pests, 2nd ed. J. M. Kraft and F. L. Pfleger, eds. American Phytopathological Society Press, St. Paul, MN.

22. Lelliott, R. A., Billing, E., and Hayward, A. C. 1966. A determinative scheme for the fluorescent plant pathogenic pseudomoands. J. Appl. Bacteriol. 29:470-489.

23. Masuda, Y., and Nishiyama, K. 2001. Occurrence of bacterial blight of pea caused by Pseudomonas syringae pv. pisi race 2. Jpn. J Phytopathol. 67:206-207. (Abstr. in Japanese.)

24. Mitchell, R. E. 1991. Implications of toxins in the ecology and evolution of plant pathogenic microorganisms: Bacteria. Experientia 47:791803.

25. Ohta, K. 1980. Occurrence of bacterial blight of pea caused by Pseudomonas syringae pv. pisi in Izu district, Japan. Ann. Phytopathol. Soc. Jpn. 46:111-112. (Abstr. in Japanese).

26. Pierce, L., and Schroth, M. N. 1994. Detection of Pseudomonas colonies that accumulate poly- $\beta$-hydroxybutyrate on Nile blue medium. Plant. Dis. 78:683-685.

27. Rademaker, J. L. W., Louws, F. J., and de Bruijn, F. J. 1998. Characterization of the diversity of ecologically important microbes by rep-PCR genomic fingerprinting. Pages 1-26 in: Molecular Microbial Ecology Manual, Supplement 3. A. D. L. Akkermans, J. D. van Elsas, and F. J. de Bruijn, eds. Kluwer Academic Publishers, Dordrecht, the Netherlands.

28. Ryu, E. 1940. A simple method of differentiation between gram-positive and gramnegative organisms without staining. Kitasato Arch. Exp. Med. 17:58-63.

29. Society of American Bacteriologist. 1957. Page 54 in: Manual of Microbiological Methods. McGraw-Hill Co., New York.

30. Suzuki, A., and Takikawa, Y.. Occurrence of apical shot chlorotic and whitening of pea caused by strains of Pseudomonas syringae pv. pisi. in: Proc. 6th Int. Conf. Pseudomonas syringae and Related Pathogens. In press.

31. Takimoto, S. 1936. Bacterial blight of pea. J. Plant Prot. Tokyo. 23:252-256. In Japanese.

32. Trimboli, D. Fahy, P. C., and Baker, K. F. 1978. Apical chlorotic and leaf spot of Tagetes spp. caused by Pseudomonas tagetis Hellmers. Aust. J. Agric. Res. 29:831-839.

33. Turner, J. G., and Taha, R. R. 1984. Contribution of tabtoxin to the pathogenicity of Pseudomonas syringae pv. tabaci. Physiol. Plant Pathol. 25:55-69.

34. Watson, D. R. W., and Dye, D. W. 1971. Detection of bacterial disease in New Zealand garden pea seed stock. Plant. Dis. Res. 55:517-521.

35. Young, J. M., and Dye, D. W. 1970. Bacterial blight of peas caused by Pseudomonas pisi Sackett, 1916 in New Zealand. N. Z. J. Agric. Res. 13:315-324.

36. Zhao, Y., Damicone, J. P., Demezas, D. H., Rangaswamy, V., and Bender, C. L. 2000. Bacterial leaf spot of leafy crucifers in Oklahoma caused by Pseudomonas syringae pv. maculicola. Plant Dis. 84:1015-1020. 